\title{
Hamsa
}

H眮MSA Journal of Judaic and Islamic Studies

$4 \mid 2018$

Varia

\section{A Contingent Nationhood: the Jewish Question and the Palestinian Cause within the Algerian Independence Movement}

Nedjib Sidi Moussa

\section{OpenEdition}

Journals

Electronic version

URL: https://journals.openedition.org/hamsa/580

DOI: 10.4000/hamsa.580

ISSN: 2183-2633

Publisher

CIDEHUS - Centro Interdisciplinar de História Culturas e Sociedades da Universidade de Évora

\section{Electronic reference}

Nedjib Sidi Moussa, "A Contingent Nationhood: the Jewish Question and the Palestinian Cause within the Algerian Independence Movement", Hamsa [Online], 4 | 2018, Online since 31 March 2018,

connection on 13 May 2021. URL: http://journals.openedition.org/hamsa/580 ; DOI: https://doi.org/ 10.4000/hamsa.580

\section{@(๑) $\Theta \Theta$}

Hamsa est mise à disposition selon les termes de la Licence Creative Commons Attribution - Pas d'Utilisation Commerciale - Pas de Modification 4.0 International. 


\title{
A Contingent Nationhood: the Jewish Question and the Palestinian Cause within the Algerian Independence Movement
}

\author{
Nedjib Sidi Moussa \\ European Centre for Sociology and Political Science \\ ndsm82@hotmail.fr
}

\begin{abstract}
Resumo:
Este artigo examina o papel, mutável em função das circunstâncias, que é dado aos judeus da Argélia, no âmbito das conceções sobre a nacionalidade argelina articuladas pelos nacionalistas argelinos - em particular, as tendências messalistas -entre as décadas de 1930 e 1980. Este aspeto é contextualizado através do apego dos nacionalistas anticoloniais argelinos à noção de uma identidade árabe-muçulmana e do mundo árabe-muçulmano, e do seu continuado apoio à causa palestina. Baseado em documentos arquivísticos pouco utilizados ou inéditos, produzidos pela polícia de Paris, pela inteligência colonial e pelo líder nacionalista Messali Hadj, este artigo demonstra como uma visão mais inclusiva da nacionalidade argelina e uma posição mais conciliadora em relação ao estado de Israel, poderia ser estrategicamente mobilizada em momentos de isolamento político.
\end{abstract}

Palavras-chave: Anticolonialismo, antisemitismo, nacionalismo, revolução, guerra

\begin{abstract}
:
This article examines the shifting place accorded to the Jews of Algeria within conceptions of Algerian nationhood articulated by Algerian nationalists - and notably those of Messalist tendencies - from the 1930s to the 1980s. This is contextualized within Algerian anticolonial nationalists' attachment to the notion of an Arab-Muslim identity and the Arab-Muslim world, and their longstanding support for the Palestinian cause. Based on a range of underused or unpublished archive material produced by the Paris police, colonial intelligence and the archives of nationalist leader Messali Hadj, the article demonstrates how a more inclusive vision of Algerian nationhood, and a more conciliatory position towards the state of Israel, could be strategically deployed at moments of political isolation.
\end{abstract}

Keywords: Anti-colonialism, anti-Semitism, nationalism, revolution, war

In his book analysing the historical relations between Palestine and North Africa, JeanPaul Chagnollaud briefly discusses the Algerian situation after the launching of the armed struggle against French colonial rule in 1954. Ignoring the Algerian National Movement (MNA) led by the old Messali Hadj, Chagnollaud's argument is based on a review of El Moudjahid, the newspaper of the National Liberation Front (FLN).Whilst only created in 1954, the FLN emerged as the hegemonic party during the Algerian revolution after marginalizing its Messalist opponents, as well as the other parties, such as the Democratic Union of the Algerian Manifesto(UDMA) ${ }^{1}$. Chagnollaud remarks that the FLN never took a position on the Palestinian issue and that Israel appears in articles in El Moudjahid as a full-fledged State ${ }^{2}$. For tactical reasons, the FLN purposefully avoided engaging in the Israeli-Arab conflict in order to avoid

\footnotetext{
${ }^{1}$ Malika Rahal, L'UDMA et les udmistes. Contribution à I'histoire du nationalisme algérien, Alger, Éditions Barzakh, 2017.

2 Jean-Paul Chagnollaud, Maghreb et Palestine, Paris, Sinbad, 1977, p. 88-89.
} 
alienating its potential foreign and domestic supporters. This article will argue that the Messalist party continued to follow - albeit readjusting its position depending on the context - the narrative sustained by Algerian nationalists since the interwar period: unconditional support for the Arab Palestinian cause and open hostility toward the State of Israel. Furthermore, in Messalist propaganda, the Zionist question was tied to the status of Algerian Jews, which was not the case for the FLN ${ }^{3}$. The Messalists go from a view in which the international context shapes how Algerian Jews are characterized (as members or not of the nation), to being excluded alongside this minority group and that experience shaping how they then revisit the international context.

This article focuses on the political contexts encouraging an exclusive or an inclusive conception of nationhood for Algerian Jews viewed through the lenses of an anti-colonial movement emerging with the "broader awakening of Arab-Muslim consciousness" 4 during the interwar period. This article seeks to demonstrate the kinds of circumstances that could help Algerian nationalists to take a more accommodating stance towards Jews and the State of Israel, despite persistent ambiguities or even anti-Semitic prejudices. To this end, this article engages with underused or unpublished material produced by the Paris police, colonial intelligence, the archives of Messali, nationalist propaganda and the anti-fascist press from the 1930s to the 1980s.

\section{Antifascism and anti-Semitic temptation}

The first pro-independence party, the North African Star (ENA), was founded in Paris in 1926, "under the aegis of the French Communist Party"5 (PCF). The ENA was led by Messali, the "founding figure of modern Algerian nationalism"6, born in 1898 in Tlemcen (western Algeria). The anti-Semitic riots which took place in August 1934 in Constantine ${ }^{7}$, an emblematic town of North African Judaism, were the first major event which provided the ENA to engage publicly in the "Jewish question". The 1870 Crémieux Decree, providing the French citizenship to Algerian Jews, caused resentment against them among the European colonists and the colonized Algerian

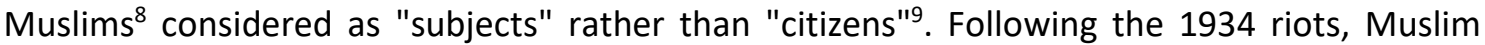
notables preached peaceful coexistence between religious communities and reaffirmed their loyalty towards France, while the nationalist revolutionary ENA supported rioters and denounced a "provocation from French imperialism" ${ }^{10}$. The Paris-based ENA's newspaper, El Ouma, even praised rioters, characterized as "heroes" or "glorious fighters", while criticizing "settlers and Jewish allies of imperialism". For El Ouma, the implementation of the Crémieux Decree justified the resentment against Jews:

\footnotetext{
${ }^{3}$ Gilbert Meynier, Histoire intérieure du FLN, 1954-1962, Paris, Fayard, 2002, p. 251-257.

4 John P. Entelis, Algeria: The Revolution Institutionalized, New York, Routledge, 2016, p. 42.

${ }^{5}$ Peter R. Knauss, The Persistence of Patriarchy. Class, Gender, and Ideology in Twentieth Century Algeria, New York, Praeger Publishers, 1987, p. 63.

${ }^{6}$ Natalya Vince, Our fighting sisters. Nation, memory and gender in Algeria, 1954-2012, Manchester, Manchester University Press, 2015, p. 41.

7 Charles-Robert Ageron, "Une émeute anti-juive à Constantine (août 1934)",Revue de l'Occident musulman et de la Méditerranée 13/14 (1973), p. 23-40; Joshua Cole, "Antisémitisme et situation coloniale pendant l'entre-deux-guerres en Algérie. Les émeutes antijuives de Constantine (août 1934)", Vingtième siècle. Revue d'histoire 108 (2010), p. 3-23.

8 Sophie B. Roberts, Citizenship and Antisemitism in French colonial Algeria, 1870-1962, Cambridge, Cambridge University Press, 2017, p. 20.

9 Michelle Mann, "The Young Algerians and the Question of the Muslim Draft, 1900-14", in Algeria Revisited: History, Culture and Identity, ed. Rabah Aissaoui and Claire Eldridge, New York, Bloomsbury, 2017, p. 51.

${ }^{10}$ Mahfoud Kaddache, Histoire du nationalisme algérien : question nationale et politique algérienne. 19191951, Alger, SNED, 1980, p. 281-282.
} 


\begin{abstract}
"Il y a plus, c'est qu'ils sont français, c'est-à-dire qu'ils sont du côté du plus fort. Ils ont trahi ceux qui leur avaient donné l’hospitalité, le titre de citoyen algérien alors qu'il y a des siècles toute l'Europe les chassait de partout ; non seulement ils n'ont jamais été reconnaissants mais profitent du fameux décret Crémieux de 1870 qui leur accorde le droit de citoyen français pour se dresser contre les Musulmans"11.
\end{abstract}

This view, ignoring the dhimmi (protected) status of the Jews under Islamic rule, was significant among Arab nationalists such as "reactionary pan-Islamist or fundamentalist"12 Shakib Arslan. His Geneva-based magazine La Nation arabe, which was very influential among North African leaders in the interwar period, followed the rhetoric of right-wing newspaper L'Action française by denouncing Jews' "arrogance"13. Indeed, on August 9, 1934 anti-Semitic and anti-republican leader of the nationalist movement Action française Charles Maurras published an editorial focused on the Constantine riots explaining that the Crémieux Decree exasperated the Arab hatred for Jews ${ }^{14}$.

The Solidarity and Action Committee for Algerian Muslims Victims of Repression in Constantine (CASMA) was created on August 16, 1934 in Paris on the initiative of Louis-Slimane Aït Ali, a French citizen born in Michelet (Kabylie) and socialist city councilor in Le Bourget (Paris suburb) ${ }^{15}$. Aït Ali was general secretary of the North African Action Committee and a member of the North African Muslims Defence League (LDMNA) whose newspaper, Le Peuple Algérien, he directed. Within the CASMA, there were at least two former Algerian activists from the PCF and the ENA: Rabah Belghoul and Abdelkader Hadjali, who had fostered Messali's communist commitment a decade earlier. The CASMA printed 4,000 copies of a leaflet distributed in Algerian cafés in the Paris region. According to the Paris police, the document did not use the word "anti-Jewish" to avoid a hostile reaction among Jewish circles. However, the text endorsed many anti-Semitic stereotypes:

\footnotetext{
"Nous connaissons la stoïque patience de nos masses paysannes. Mais nous connaissons également l'insatiable cupidité des financiers juifs, leur arrogance de parvenus, leur incomparable et antique talent à nous détrousser et à nous ruiner.

Le colon féodal exploite notre prolétariat agricole - le plus misérable du monde ! - Les spéculateurs et les usuriers issus d'Israël, s'engraissent des dépouilles de nos commerçants et de nos paysans moyens et les acculent à la faillite par leurs savantes manœurres.

La carence de cette institution vermoulue et malfaisante qu'est le Gouvernement général, a empêché depuis un siècle, l’organisation du Crédit agricole et commercial en faveur de nos classes moyennes. Cette attitude coupable a livré tout un peuple de travailleurs aux Gangsters de I'Usure et du Négoce"16.
}

In addition, the CASMA circulated a subscription list among the North African diaspora in Paris to send a lawyer in Algeria. Its leaders also spread the word that Muslims in Constantine

\footnotetext{
${ }^{11}$ Mahfoud Kaddache, Histoire du nationalisme algérien..., p. 300.

${ }^{12}$ Gilbert Achcar, Les Arabes et la Shoah. La guerre israélo-arabe des récits, Arles, Sinbad-Actes Sud, 2009, p. 191-199.

13 "Autour des événements de Constantine", La Nation arabe, $\mathrm{n}^{\circ} 1$, septembre-octobre 1934.

14 Pascal Blanchard, "La vocation fasciste de l'Algérie coloniale dans les années 1930", in De l'Indochine à l'Algérie. La jeunesse en mouvement des deux côtés du miroir colonial, ed. Daniel Denis, Youssef Fates and Nicolas Bancel, Paris, La Découverte, 2003, p. 182.

15 Rapport (21 août 1934), in Préfecture de Police de Paris (PPP), carton BA 2171, dossier "2 ${ }^{\text {ème }}$ partie. Etoile nord-africaine".

16 "Comité d'Action et de Solidarité en faveur des Musulmans Algériens victimes de la répression à Constantine" and "Appel aux Musulmans Algériens résidant en France !", in PPP, carton BA 2171, dossier "2 ${ }^{\text {ème }}$ partie. Etoile nord-africaine".
} 
were thrown out of windows or drowned in the Rhumel River. According to the Paris police, the Algerian diaspora "whose critical awareness was not very developed"17 were gullible and susceptible to believing these rumors. However, CASMA's fundraising hopes were quickly dashed because the monies collected were insufficient to achieve its goals ${ }^{18}$. Nevertheless, most of the Algerian associations in the Seine department supported the CASMA at the time of its creation, with the notable exception of the ENA. This specificity can be explained by two events.

Following the massive demonstration organized by various French fascist organizations ${ }^{19}$, including anti-socialist, anti-Masonic and anti-Semitic French Solidarity, on February 6, 1934 in Paris, Messali offered ENA's help to the socialists to counter the influence of right-wing groups among Algerian workers ${ }^{20}$. Then, a thawing began in mid-July between the PCF, driven by André Ferrat ${ }^{21}$, and ENA's leaders, Messali being the first and foremost ${ }^{22}$. The Constantine riots contributed to a new alliance between the PCF and the ENA ${ }^{23}$. The CASMA sought to deploy its activity to compete with that of the ENA. CASMA's prominent members were in conflict with both the PCF and the ENA. The ENA had opened a subscription or held meetings about the Constantine riots. For the Paris police, the leaders of the CASMA and the ENA "sought to profit from the events, by exploiting for that purpose the instinctive antiSemitism of their co-religionists" 24 . However, the ENA faced repression from the French authorities. An attempt to hold a public meeting on October 13, 1934 in the Grange-aux-Belles was scuppered by the French authorities banning their use of the conference room ${ }^{25}$. The organizers sought another venue for the meeting, and some Algerians did attend. The speakers, Messali, Amar Imache, Belkacem Radjef and Mrs. Longuet did not raise the topics which had been listed on the agenda, namely, the Constantine riots and events in Tunisia. Instead, they just talked about police repression and the violation of freedom of assembly.

In the end, the CASMA did not receive significant support among the Algerian diaspora compared to the ENA. However, this series of events enables us to see how sensitive the Jewish question was for Algerian nationalists. It also invites reflection on the "permeability" between fascist and pro-independence activists ${ }^{26}$. Born into a marabout (notable) family from Kabylie and trained in a medersa (college) in Algiers, nationalist activist Foudil Larabi exemplified this phenomenon. As a member of ENA's executive, Larabi attended a nationalist meeting in May 1934 at the inter-union conference room, located in the $15^{\text {th }}$ arrondissement of Paris ${ }^{27}$. His speech was laden with Koranic verses and Arab proverbs. He called for a boycott of French goods and concluded with the motto: "Kill those who step back, follow those who move forward and avenge their death". At this event, Ait Ali spoke on behalf of the LDMNA, which Larabi himself

\footnotetext{
17 Rapport (22 août 1934), in PPP, carton BA 2171, dossier "2 ${ }^{\text {ème }}$ partie. Etoile nord-africaine".

${ }^{18}$ Rapport (15 décembre 1934), in PPP, carton BA 2171, dossier "Comité d'action et de Solidarité en faveur des Musulmans Algériens victimes de la Répression à Constantine".

${ }^{19}$ Robert J. Soucy, "France", in The Social Basis of European Fascist Movements, ed. Detlef Mühlberger, Oxford, Routledge, 2016, p. 203.

${ }^{20}$ Daniel Guérin, Ci-gît le colonialisme. Algérie, Inde, Indochine, Madagascar, Maroc, Palestine, Polynésie, Tunisie. Témoignage militant, Paris, Mouton, 1973, p. 14-15.

21 Céline Marangé, "André Ferrat et la création du Parti communiste algérien (1931-1936)", Histoire@Politique. Politique, culture, société 29 (mai-août 2016), p. 190-219.

${ }^{22}$ Benjamin Stora, Nationalistes algériens et révolutionnaires français au temps du Front populaire, Paris, L'Harmattan, 1987, p. 34.

${ }^{23}$ Claude Liauzu, Aux origines des tiers-mondismes. Colonisés et anticolonialistes (1919-1939), Paris, L'Harmattan, 1982, p. 43.

${ }^{24}$ Rapport (24 septembre 1934), in PPP, carton BA 2171, dossier "Comité d'action et de Solidarité en faveur des Musulmans Algériens victimes de la Répression à Constantine".

25 Rapport (30 octobre 1934), in PPP, BA 2171, dossier "Comité d'action et de Solidarité en faveur des Musulmans Algériens victimes de la Répression à Constantine".

${ }^{26}$ P. Blanchard, "La vocation fasciste de l'Algérie coloniale...", p. 190.

${ }^{27}$ Rapport (26 mai 1934), in PPP, BA 2171, dossier "2 ${ }^{\text {ème }}$ Partie. Etoile nord-africaine".
} 
joined soon after. In a meeting held in December 1934, Larabi called for all Muslims to unite ${ }^{28}$. Following the turmoil which followed the anti-Semitic Constantine riots and the Popular Front's policy towards North Africa, Larabi joined Jacques Doriot's French Popular Party (PPF) in October 1938. With Djilali Bentami - the future representative of the Algerian Red Crescent in Geneva he became a leader of this fascist party which advocated the abrogation of the Crémieux Decree and the withdrawal of the 1936 Blum-Viollette proposal, which planned to give access to full French citizenship to a minority of Algerian Muslims.

\section{Algeria, Zionism and the Cause of Arab Palestine}

The Jewish question resurfaced through the cause of Arab Palestine promoted by the Algerian nationalists. Echoing the Arab revolt in Palestine, these topics provoked lively discussion during a meeting organized by the Anti-Imperialist League (LAI) on June 19, 1936 at the Sociétés Savantes conference room in Paris ${ }^{29}$. According to the Paris police, LAI president Francis Jourdain asked the audience to listen quietly to the speakers. The ENA's first speaker regretted the fighting between Arabs and Jews in Palestine. He then called for reconciliation "by making them understand that they are all victims of capitalism and English imperialism". A member of the radical-socialist party also criticized English policy in Palestine. However, the situation deteriorated when a member of the Human Rights League (LDH) claimed his "pride in belonging to the Jewish race" and tried to demonstrate that Palestine belonged to the Jews. His speech gave rise to protests and the chairperson was forced to call the meeting to order. This member of the radical-socialist party was then contradicted by a representative of Jewish workers who denounced Zionism and the "perfidious Albion", while claiming equality of rights and duties for the Jewish worker in his country of birth. The ENA's second speaker, Messali, was much applauded and he was welcomed by the Internationale anthem. He criticized British imperialism, "even more odious than French imperialism". Messali explained that, "the hand of England was behind the Jewish people" who in turn would be sacrificed if they misunderstood "the unhealthy work of Zionism". He then called for Arabs and Jews to unite and concluded by criticizing the LDH's speaker. At the end of the meeting, the audience agreed to denounce fascism, imperialism and anti-Semitism.

El Ouma regularly echoed interest in the Palestinian issue by publishing original articles written by Algerian nationalists ${ }^{30}$ or Independent Labour Party's member Geoffrey Bagot ${ }^{31}$ and by reproducing papers from La Nation arabe, which associated anti-Zionism with an anti-Semitic rhetoric $^{32}$. Despite this notorious opposition to Zionism, the head of the International League against Anti-Semitism (LICA), Bernard Lecache, issued in July 1936 a fraternal appeal to Messali to collectively fight exploitation, racism and fascism ${ }^{33}$. At this time, French democratic and antifascist circles expressed their concerns that European fascists were influencing North Africans and Algerian Muslims in particular ${ }^{34}$. Lecache's attempt faced several challenges, as historian

\footnotetext{
${ }^{28}$ Rapport (15 décembre 1934), in PPP, BA 2171, dossier "Comité d'action et de Solidarité en faveur des Musulmans Algériens victimes de la Répression à Constantine".

${ }^{29}$ Rapport (Paris, 20 juin 1936), in PPP, carton HA 26, dossier "4 560103 Messali Hadj; activités politiques, séjours à Paris (1925-1937)".

${ }^{30}$ A. Yahiaoui, "La Palestine martyre", El Ouma, décembre 1937; "En Palestine : les méfaits du sionisme", El Ouma, 27 août 1938.

${ }^{31}$ Geoffrey Bagot, "La Vérité sur la Palestine", El Ouma, 25 octobre 1938.

32 "L'acharnement des juifs contre le Grand Mufti de Jérusalem", El Ouma, mars 1939.

${ }^{33}$ Bernard Lecache, "Musulmans, nos frères...", Le Droit de vivre, 18 juillet 1936.

${ }^{34}$ Comité de vigilance des intellectuels antifascistes, La France en face du problème colonial, 1936; Gabriel Péri, Ombres du fascisme sur l'Afrique du Nord. Collection d'articles parus dans L'Humanité après une enquête en Afrique du Nord, Paris, Éditions du Comité populaire de propagande, 1938.
} 
Emmanuel Debono has noted ${ }^{35}$ : the ENA expressed its agreement to cooperate with the LICA only if the league "breaks with Zionism"; rumors concerning the "alleged anti-Semitic views" of Messali, spread by far-right intellectual Henry Coston, troubled the LICA; the LICA backed the Blum-Viollette proposal while Messali condemned it "for giving the right to vote to some 25,000 bourgeois Algerians while leaving six millions fellahs [peasants] in misery"36. A key issue which separated the radical ENA from the progressive LICA was that it was easier for the LICA to talk with the moderate Muslim elite of Algeria, who did not stand for the end of French rule in North Africa, whilst for the ENA these notables were their political enemies. However, the friendship between Messali and Lecache that began in 1935 for the Popular Front ${ }^{37}$ did not break definitively and would see further developments during the Algerian revolution 1954-1962.

During the Second World War, the pro-fascist Vichy regime abrogated the Crémieux Decree in 1940 and "even after the Allies ended the Vichy administration [in 1942], the Decree was not restored and systemic discrimination continued" 38 against Algerian Jews. However, in January 1943, the Governor-General of Algeria Marcel Peyrouton" proposed several improvements of Algerian Jews' status" ${ }^{139}$. Messali's wife Emilie Busquant told an official from the General Government of Algeria that the "measures granted to Jews" had a negative impact among Algerian Muslims who were "upset to remain excluded"40. These limited measures covered the reintegration of 3,500 Jewish officials fired by the Vichy regime and the abandonment of the numerus clausus disposition applied to lawyers, physicians and students in Algeria ${ }^{41}$. Messali's refusal to collaborate with Maréchal Pétain and his advocacy for the rights of Jews earned him a very positive article in a periodical close to the British Labour Party in December $1946^{42}$. Described as the "Algerian Gandhi", Messali was quoted as stating that the universal suffrage he claimed in Algeria was also for Christians and Jews. Nevertheless, this inclusive approach towards Algerian Jews took a new turn as the partition of Palestine approached. The nationalist underground newspaper, La Nation algérienne, devoted an article to this topic:

"Dans divers endroits, les organisations sionistes d'Algérie ont organisé des camps de préparation militaire où le maniement d'armes bat son plein. Le transport des éléments sionistes et des armes vers la Palestine s'effectue sur divers points de la côte algérienne"43.

In May 1947, the Governor-General of Algeria noted a rise in Zionist activities, especially in the Oran department in western Algeria ${ }^{44}$. Until then, this movement had little impact among Algerian Jews despite the propaganda of Zionist organizations such as Betar, a right-wing youth movement ${ }^{45}$. Nonetheless, it was noted that volunteers, mostly from Morocco, were selling their

\footnotetext{
35 Emmanuel Debono,"Le rapprochement judéo-musulman en Afrique du Nord sous le Front populaire. Succès et limites", Archives Juives 45 (2012), p. 94-95.

${ }^{36}$ Allison Drew, We are no longer France. Communists in colonial Algeria, Manchester, Manchester University Press, 2014, p. 99.

${ }^{37}$ Messali Hadj, "La dissolution de l’Etoile nord-africaine", La Gauche révolutionnaire, n¹5, $1^{\mathrm{er}}$ mars 1937.

${ }^{38}$ Phillip C. Naylor, Historical Dictionary of Algeria, Lanham, The Scarecrow Press, 2006, p. 299.

${ }^{39}$ Sophie B. Roberts, Citizenship and Antisemitism in French colonial Algeria..., p. 299.

${ }^{40}$ Renseignements (Alger, 13 février 1943), in Centre des archives d'outre-mer (CAOM), carton 4 I 147, dossier "Madame Messali, née Busquant Emilie".

${ }^{41}$ Benjamin Stora, "L'impossible neutralité des Juifs d'Algérie", in La guerre d'Algérie 1954-2004. La fin de l'amnésie, ed. Mohammed Harbi and Benjamin Stora, Paris, Robert Laffont, 2004, p. 423.

42 "La voix éternelle de I'Islam", News Review, 24 décembre 1946.

43 "Avec le peuple arabe de Palestine contre l'impérialisme sioniste", La Nation algérienne, n¹3, 1947.

${ }^{44}$ Courrier du gouverneur général de l'Algérie au ministre de l'Intérieur (Alger, 28 mai 1947), in Ministère des Affaires étrangères (MAE), Direction Afrique/Levant, carton 5, dossier "Algérie. Questions politiques. Affaires juives - sionisme. Juillet 1946 - mars 1948".

45 Yaacov Shavit, Jabotinsky and the Revisionist Movement 1925-1948, New York, Frank Cass \& Co., 2005, p. 51-57.
} 
belongings and trying to migrate illegally to Palestine. The anti-Arab and anti-British activities of "ultra-nationalist dissident armed group"46 Irgun in Palestine, accelerated this enthusiasm for migration according to the Governor-General of Algeria ${ }^{47}$. Furthermore, several organizations, including the Algerian Zionist Federation and the Revisionist Zionist Union of Algeria, asked the French Ministry of Foreign Affairs to support their request addressed to the United Nations against the execution of Irgun's activist Dov Gruner ${ }^{48}$.

The activity of Algerian nationalists in favor of Palestine's Arabs resumed more intensely after the partition plan adopted by the United Nations in November 1947. The following month, the Gendarmerie noted that a leaflet was distributed in Aïn-Beïda (eastern Algeria) ${ }^{49}$. Titled "Against any partition of Palestine, for an Arab, free and independent Palestine", this document was reproduced in the nationalist newspaper El Maghrib Al Arabi on December 13, 1947. In AinBeïda, pro-independence leader Mohammed Zinaï, a 44-year-old Arab teacher, was suspected of organizing meetings in cafés to call young Algerian Muslims to enlist in the Arab Legion of Palestine.

Mostefa Stambouli was another nationalist leader engaged in the Palestinian cause. On January 6, 1948, at the age of 28, he left his hometown of Mascara (western Algeria) to reach Palestine and was said to have recruited around twenty people to follow him. He made a halt in Tunis, from where he planned to continue his journey Egypt, according to colonial intelligence ${ }^{50}$. Abdelhamid Mehri and M'Hamed Ferhat, both Algerian nationalist students in the Zitouna University, hosted Stambouli51. After passing Tripolitania, the British police arrested him. In February 1948, the Sfax Court gave Stambouli a suspended sentence of 15 days imprisonment and fined him 1,000 Francs for not holding a passport ${ }^{52}$. He then went back to Mascara. His comrade Ferhat had a very similar experience. In Tunis, he tried to form a group of fighters before the British police in Tripolitania arrested him ${ }^{53}$. Back in Mascara, wounded, he tried to organize activists to fight in Palestine.

In Algeria, other political initiatives followed these attempts to fight arms in hand for the Palestinian cause. On June 2, 1948, the Algerian Assistance Committee for Palestine ${ }^{54}$ was launched after an agreement between Messali's post-Second World War party, the Movement for the Triumph of Democratic Liberties (MTLD), the UDMA, led by moderate Ferhat Abbas and sheikh Brahimi for the Association of Algerian Ulama (Muslim theologians). The Committee for Palestine criticized both capitalists and communists and called Algerians to support this action on behalf of "their ardent Arab patriotism and their Islamic faith"55. Yet, the MTLD quickly left

\footnotetext{
${ }^{46}$ Dorothy Willner, Nation-Building and Community in Israel, Princeton, Princeton University Press, 1969, p. 121.

${ }^{47}$ Courrier du gouverneur général de l'Algérie au ministre des Affaires Etrangères (Alger, 22 mai 1947), in MAE, Direction Afrique/Levant, carton 5, dossier "Algérie. Questions politiques. Affaires juives - sionisme. Juillet 1946 - mars 1948".

48 Télégramme au ministère des Affaires Etrangères (16 mai 1947), in MAE, Direction Afrique/Levant, carton 5, dossier "Algérie. Questions politiques. Affaires juives - sionisme. Juillet 1946 - mars 1948".

49 Rapport de la gendarmerie (Guelma, 27 décembre 1947), in Centre d'accueil et de recherche des archives nationales (CARAN), carton BB 18 3613, dossier "Organisation paramilitaire découverte en mars 1950".

${ }^{50}$ Notice individuelle (Mascara, 22 janvier 1948), in CAOM, carton 5 I 26, dossier "Stambouli Mostefa".

51 Interview with Abdelhamid Mehri in Algiers, 3 December 2008.

52 SEGLNA, notice individuelle (7 janvier 1957), in CAOM, carton 5 I 26, dossier "Stambouli Mostefa".

53 Salah Ziad, "Maître Ferhat M'Hamed: Celui que Messali surnommait 'Chograni'", Le Quotidien d'Oran, 16 juillet 2008; Kaddour Tegguer, "Evocation: I'IRDH rend hommage à feu Maître M'Hamed Ferhat", EI Watan, 28 décembre 2011.

54 "Dans l'union de toute l'Algérie musulmane. Un comité d'aide à la Palestine est créé en Algérie", Egalité, n¹29, 6 juin 1948; "À propos du comité algérien d’aide à la Palestine. Les responsabilités sont désormais situées", Egalité, n¹31, 18 juin 1948.

55 Benyoucef Ben Khedda, Les origines du $1^{\text {er }}$ novembre 1954, Alger, Dahlab, 1989, p. 285-286.
} 
this collective initiative. The MTLD's claim to hegemony and its Arab-Muslim narrowmindedness put an end to any attempt to bring different organizations together through the Palestinian cause. Under the guise of anti-imperialism, Messalist leaders used religious symbols and some of them advocated boycotting Jewish merchants, which appeared contrary to UDMA's more inclusive principles ${ }^{56}$. A few local committees were launched such as the one chaired by Zinaï in Aïn-Beïda. Then considered as the "real master of the city" by colonial intelligence, Zinaï organized a fundraising event for Palestine in September 1948:

"Cette collecte a obtenu un réel succès. Soit par conviction, soit par crainte, soit par honte, tous les Musulmans ou presque ont versé leur obole. Le taux des versements variait entre 200 et 3000 francs. Les donateurs ont obtenu un récépissé de versement" ${ }^{157}$.

While passing through Cairo in October 1951, Messali met with former Jerusalem Mufti Hadj Amin Al-Husseini, who represented no one but himself at this time ${ }^{58}$. The following month, Messali met with Ahmed Hilmi Pacha, head of a "shadow" Palestinian government. From that moment onward, the Palestinian issue was not raised anymore, apart from the international section of the MTLD's newspaper L'Algérie libre.

\section{Brotherhood or Friendship between Communities?}

Two years after the FLN launched the armed struggle for Algeria's independence, the latest incarnation of the Messalist party, the MNA, appealed directly to the Algerian Jews in a leaflet found by the French army on September $17,1956^{59}$ and reproduced in the $25^{\text {th }}$ issue of MNA's newspaper La Voix du Peuple in September 1956. The appeal was a response to a group of Jews from Constantine who circulated a document, highlighting their belonging to the Algerian nation in August $1956^{60}$, three months after the events that occurred in Constantine on May 12, 1956. On this date, the Misgeret - a special force established by Mossad to promote Aliyah and self-defense for the Jewish community ${ }^{61}-$ launched its first operation in Algeria. This force gathered a hundred young Jews from Constantine and conducted violent operations in response to the FLN's terror attacks in the city which also targeted Jewish businesses. For months, the Misgeret and the FLN launched terror attacks and anti-terror operations against each other, despite the attempts of the French military authorities to "calm the situation"62, spreading fear among the population of Constantine. In this tense context, the MNA's propaganda was neither fraternal nor friendly towards Algerian Jews:

\footnotetext{
${ }^{56}$ Malika Rahal, L'Union démocratique du Manifeste algérien (1946-1956). Histoire d'un parti politique. L'autre nationalisme algérien, Paris, INALCO, 2007, p. 136.

57 SLNA (Constantine, 20 septembre 1948), in CAOM, carton 93 4295, dossier "Zinaï Hadj Belgacem".

58 Jean-Paul Chagnollaud, Maghreb et Palestine..., p. 86.

59 "Aux Juifs d'Algérie en général, aux Juifs de Constantine en particulier", in Service historique de la Défense (SHD), carton 1 H 2592, dossier "D 6".

${ }^{60}$ Frantz Fanon, Sociologie d'une révolution. L'an V de la révolution algérienne, Paris, François Maspero, 1972, p. 147.

${ }^{61}$ Michael M. Laskier, North African Jewry in the Twentieth Century: The Jews of Morocco, Tunisia and Algeria, New York, New York University Press, 1994, p. 319; David Cohen, "Algeria", in The Jews of the Middle East and North Africa in Modern Times, ed. Reeva S. Simon, Michael M. Laskier and Sara Reguer, New York, Columbia University Press, 2003, p. 468.

62 "Graves incidents à Constantine. Treize morts", Le Monde, 14 mai 1956; "Dix-neuf tués samedi lors d'une fusillade qui suivit le lancement d'une grenade dans un café. Six tués dimanche à la suite d'une panique qui s'est emparée d'un groupe d’Européens", Le Monde, 15 mai 1956; "Vingt-cinq musulmans tués en deux jours à Constantine", Le Monde, 15 mai 1956; "Le général Noiret: se laisser aller à l'aveugle vengeance serait faire le jeu de l'adversaire", Le Monde, 15 mai 1956.
} 


\begin{abstract}
"Que firent les Juifs pendant cette appréciable période durant laquelle les musulmans, brimés, oppressés, mouraient et remplissaient les prisons? RIEN, sinon qu'ils profitaient, en complicité avec les tenants d'un régime rétrograde, d'une existence plus que bourgeoise et organisaient ce qu'ils prétendaient être une 'vie assurée'. Et cela au prix de ce dont ils se réclament aujourd'hui. Mieux encore, contrariant avec une intention ahurissante les nécessités vitales du peuple algérien, ils firent preuve d'un inlassable dévouement et de sacrifice remarquable pour une cause étrangère, en l'occurrence l'affaire palestinienne. II est néanmoins heureux de constater que deux années d'insurrection armée leur ont permis de se découvrir avec exactitude. Faut-il encore se présenter sans équivoque et sans rusée manœuvre.

Les 'FILS d'une même terre' sont des FRERES et il n'y a que deux étrangers qui cherchent l'amitié. De plus quand on est 'partie intégrante du peuple algérien' on doit partager les souffrances de ce peuple ainsi que sa lutte. On ne doit pas s'en éloigner et d'abord 's'unir avec la France libérale'".
\end{abstract}

This hostile statement issued by the MNA contrasted with that of the FLN, which promised the Jewish minority to "safeguard its happiness in independent Algeria" at the Soummam Congress in August $1956^{63}$. Two months later, the FLN released an "Appeal to our Israelite compatriots", describing Algerian Jews as "sons of our homeland" while asking the Jewish community to "solemnly proclaim their membership of the Algerian nation" to clear up misunderstandings. Despite the ambiguities of this statement, the FLN's leaders, notably those who were more left-leaning, did not exclude Jews from Algerian nationhood. In fact, the FLN's French Federation leader Mohammed Harbi participated in the creation of an Algerian Jews Committee for Independence at this time ${ }^{64}$. From a Messalist perspective, two factors meant that the MNA's conception of Algerian nationhood had to be an exclusive one. Firstly, the massive francization of Algerian Jews ${ }^{65}$; secondly, the Algerian Jews' support for Israel, even though Algerian Jews were few in number to migrate to Palestine compared to other North African Jewish communities.

By the end of 1956, the Suez crisis offered another opportunity for the MNA to express its anti-Zionist rhetoric. The MNA strongly criticized French leaders Robert Lacoste and Guy Mollet, whom they labelled "Zionist". The socialist Prime Minister Mollet was even described as "the man of Zionism, [leading] all-out war in Algeria, [and] armed aggression against Muslim and Arab peoples"66. La Voix du Peuple published a long article, extremely violent and even threatening, which denounced an "Israeli-colonialist conspiracy":

\begin{abstract}
"Mais, M.M. les impérialistes et vos journalistes valets à la solde de la Presse colonialiste parlons y de cet Etat d'Israël. Qu'est-ce donc Israël sinon le dernier bastion du colonialisme en Proche-Orient - et les derniers événements viennent encore confirmer que cet Etat artificiel n'est rien d'autre que la plateforme à partir de laquelle un impérialisme aux abois cherche à regagner ses anciennes positions. Laissé à lui seul, l'Etat d'Israël est une création non-viable ; seule la 'générosité' colonialiste conjuguée avec la Finance juive arrive à lui insuffler un semblant de vie. L'Etat d'Israël entretient ainsi sur pied une armée qui n'a aucun rapport avec ses ressources économiques des plus réduites et cela grâce à la manne impérialiste. (...)
\end{abstract}

En agissant contre le peuple frère d'Egypte, l'Angleterre et la France se couvrent de honte. L'humanité apprendra avec soulagement la nouvelle de l'écroulement d'Israël. (...)

\footnotetext{
63 Benjamin Stora, "L’impossible neutralité des Juifs d'Algérie...", p. 430-432.

${ }^{64}$ Mohammed Harbi, Une vie debout. Mémoires politiques. Tome 1: 1945-1962, Alger, Casbah, 2001, p. 200.

65 Joëlle Allouche-Benayoun, "Les enjeux de la naturalisation des Juifs d'Algérie : du dhimmi au citoyen", in Le choc colonial et l'islam. Les politiques religieuses des puissances coloniales en terre d'islam, ed. PierreJean Luizard, Paris, La Découverte, 2006, p. 193-194.

66 "Lacoste et Guy Mollet aux abois", La Voix du Peuple, n²7, [novembre 1956].
} 
Quant à Israël, tous les peuples de la terre savent que c'est un État factice, un instrument de l'impérialisme occidental. Les Arabes se chargeront de lui régler son compte et un beau matin, I'humanité apprendra avec soulagement sa disparition de la carte mondiale"67.

This anti-Israeli statement was reaffirmed in a leaflet expressing the MNA's views on the French army hijacking of a plane carrying FLN leaders, the Hungarian revolution and the "cowardly assault against the brotherly Egyptian people": "Regarding the fake State of Israel, creature of the Western imperialism, it constitutes a permanent trouble spot. Only its elimination as a State could bring peace and security in the Middle East"68. The Western intervention in Egypt created new tensions in Algeria. According to the French newspaper Le Monde, an anti-Semitic leaflet circulated in Oran (western Algeria), while the Jews of this city received threatening letters ${ }^{69}$. The article referred to the possibility that some "lost Muslims" could not distinguish between Jews and Israelis.

It took more than two years to establish contacts between Israelis and Messalists, despite the long-standing hostility of the MNA towards the State of Israel and its exclusionary attitude towards Algerian Jews. In May 1959, Messali's representative in England, Mohammed Saadoun, a 33-year-old former Arabic teacher from Collo (eastern Algeria), met with Israel Neumann, the Paris correspondent of the Israeli Labour newspaper Davar. Historian Michael M. Laskier uncovered the traces of this meeting in the Israeli diplomatic archives:

\begin{abstract}
"The message conveyed by the MNA was that the formation of the Syrian-Egyptian Union in 1958 was causing consternation among its members. Their activists opposed Nasser, who openly sided with their FLN opponents. Saadoun disavowed any ties to the Arab League, whose policies the MNA found objectionable, but admitted that all Algerians could ill-afford to disregard the intense passions unleashed by the Middle Eastern Arab states against Israel. The Israeli issue was complicated by the fate of 'one million Palestinian refugees' with whom the Arabs sympathized. The Middle East needed, first and foremost, a program for social reforms to raise economic standards. Only then would the negative passions engendered by Nasserism fade and official recognition of Israel be forthcoming"70.
\end{abstract}

Messali also met with Neumann who published an interview with the Algerian leader in Davar in May 1961. According to Laskier ${ }^{71}$, Messali's statements were quite evasive about the Israeli-Arab conflict. However, the MNA president expressed the desire that Algeria would play, in a foreseeable future, a facilitating role between the different nationalist tendencies in the Middle East, instead of exacerbating tensions. The Messalist resentment against the Egyptian President Gamal Abdel Nasser and the Arab League, accused of favoring the FLN over the MNA, could explain this unlikely relation.

\title{
4. Temporary Opening, Long-Lasting Support and Nostalgia
}

This late opening followed the publication in April 1961 in La Voix du Peuple of an article titled "Our compatriots of European and Jewish origins will be full members of the Algerian

\footnotetext{
67 "Machination israélo-colonialiste", La Voix du Peuple, $\mathrm{n}^{\circ 27}$, [novembre 1956].

68 MNA, "Malgré toutes les manœuvres d'étouffement, le MNA fait connaître ses positions", in Archives de Messali Hadj (AMH).

69 "La masse musulmane algérienne saura-t-elle toujours distinguer entre Israélites et Israéliens ?", Le Monde, 2 novembre 1956.

70 Michael M. Laskier, "Israel amid French Colonialism and the Arab-Israeli Conflict, 1954-1978", Israel Studies 6 (2001), p. 9-10.

${ }^{71}$ Michael M. Laskier, "Israel and the Maghreb at the Height of the Arab-Israeli Conflict: 1950s - 1970", The Middle East Review of International Affairs (MERIA) 4-2(June 2000), p. 96-108.
} 
Republic". On behalf of Muslim Algerians, this paper welcomed the ongoing "revolution" among the "non-Muslim Algerian community" which was in the process of freeing itself from procolonial activists' tutelage. The Messalist newspaper stated that any discomfort, fear or uncertainties remaining among non-Muslim Algerians about an Algeria freed from French rule were not justified because Muslim Algerians did not lack "tolerance and goodwill". La Voix du Peuple welcomed the creation of the Liaison Committee of Liberal and Democratic Groups of Algeria, which sought "peace, negotiation and cohabitation between communities"72. The MNA's newspaper referred also to a study by Jacques Lazarus, envoy of the World Jewish Congress to Algeria, published in his Algiers-based periodical Information Juive. Reproducing Lazarus's core argument, the MNA called for the self-determination of Algerian Jews:

\begin{abstract}
"Enfants du peuple algérien, que nous soyons chrétiens, israélites, musulmans ou libres penseurs, de gré ou de force, nous devons continuer à vivre ensemble et préparer à nos enfants un bel avenir. Débarrassés de tous les préjugés et complexes engendrés par le régime colonial nous saurons, les uns et les autres, faire œuvre utile et conduire notre pays dans la voie de la démocratie, du progrès social et de la civilisation moderne".
\end{abstract}

In this very inclusive plea, which described Algerian Jews as "compatriots", the Palestinian cause was not discussed anymore. This significant change in attitude from the Messalist party towards Algerian Jews can be understood as a result of the MNA's defeat to the hegemonic FLN, in their competition for the legitimacy to represent the Algerian people. On the eve of Algerian independence, the Messalists, who since the interwar period had been intransigent anti-colonialists, became members of a marginalized political community threatened with destruction and exile - just like the Europeans and Jews of Algeria. This is one explanation for why the MNA adopted a more inclusive attitude towards these minorities and tried to gain their support.

Yet Messali's archives offer other suggestions to understand this evolution. Following the attempted murder of Messali by the FLN in September 1959, the president of the LICA, Lecache, sent a friendly letter to the MNA president and asked him to send a message to his newspaper Le Droit de vivre ${ }^{73}$. In response to this request from his "old comrade", Messali replied that the newspaper and its director were "sympathetic and old acquaintances"74. The Algerian nationalist added that they reminded him of "the past times of our struggle and our hopes" before underlining that he remained the same person, "servant of democracy, the Algerian people and all the oppressed". Lecache then "fraternally" thanked Messali, highlighting their "longstanding friendship"75, before publicly stating in his newspaper that the Algerian leader was another "valid interlocutor" for peace negotiations with the French government. At the beginning of 1960, the LICA president asked Messali to send an article or a statement to be published in Le Droit de vivre to make "the voice of the MNA" heard ${ }^{76}$. Messali sent the requested article preceded by a personal message to Lecache in which he criticized the conspiracy of silence" against his movement and the attitude of "French democracy"77. Criticizing implicitly the FLN and its French allies, Messali added with bitterness that a "political group [had] prostituted the Algerian revolution" and that the "French left [had] prostituted French socialism". Lecache acknowledged receipt of this message and agreed with Messali about the "conspiracy of silence" against the MNA before expressing his respect for Charles de Gaulle.

\footnotetext{
72 "Création d'un comité de liaison des groupements libéraux et démocratiques d'Algérie", Le Monde, 13 février 1961.

${ }^{73}$ Lettre de Bernard Lecache à Messali Hadj (Paris, 18 septembre 1959), in AMH.

74 Lettre de Messali Hadj "à mes amis du journal Le Droit de vivre et à ses lecteurs" (Gouvieux, 20 septembre 1959)" in AMH.

75 Lettre de Bernard Lecache à Messali Hadj (Paris, 22 septembre 1959), in AMH.

${ }^{76}$ Lettre de Bernard Lecache à Messali Hadj (Paris, 25 février 1960), in AMH.

77 Lettre de Messali Hadj à Bernard Lecache (Gouvieux, 2 mars 1960), in AMH.
} 
MNA's newspaper La Voix du Peuple referred to the publication of Messali's article in Le Droit de vivre $^{78}$. This renewed contact between the two activists does not appear to have lasted long, probably because of the refusal of Messali's movement to be used as an excuse for the French government to delay negotiations with their rivals, the FLN's Provisional Government of the Algerian Republic (GPRA).

According to Messali's archives, two months before the proclamation of Algeria's independence, there were two Israelis among the journalists invited to cover Messali's press conference on May 4, 1962 in Gouvieux (North of Paris) ${ }^{79}$ : Samuel Segev for Maariv and Michael Bar-Zohar for La Merhav. Messali repeated his commitment to the goal of North African unity ${ }^{80}$, and expressed the wish that "independent Algeria could have productive relationships with all the Mediterranean countries"1. This topic was then discussed during the question and answer session:
"Q.: M. le Président, en parlant de relations fructueuses avec tous les pays méditerranéens, est-ce que, vous aussi, vous mettez Israël dans ces pays méditerranéens ?
R. : Ecoutez, la démocratie, Monsieur, n'a pas de limite ; lorsque le peuple algérien sera libre et indépendant, il envisagera ce problème et il donnera une réponse définitive et officielle à ce moment-là"82.

Messali's answer about Israel remained evasive but hinted at a potential overture, however tactical it might be, and a break from the radical statements expressed by the MNA in 1956. In Algeria, however, the "Jewish question" ended in summer 1962 with the massive exile of the Jewish population, which had been present in this part of North Africa for many centuries. Algerian Jews, like Europeans, harkis (auxiliaries) and even the last remaining Messalists ${ }^{83}$, fled their homeland "in fear of reprisals, ongoing violence, economic upheaval, and uncertainty" 84 . Only a minority reached the State of Israel while the vast majority decided to migrate to France, the country of which they were citizens.

In Messali's archives, several documents illustrate the long-lasting interest of the Algerian leader for the Palestinian cause, which was generally not contextualized in relation to the situation of Algerian Jews. After Algerian independence, Messali collected statements issued by the Popular Front for the Liberation of Palestine (PFLP) or Fatah. In March 1969, he reproduced a statement from Fatah in his newspaper Le Cri du peuple algérien. This expression of pro-Palestinian sentiment followed the Six Day War and was proof of Messali's support for the Arab-Muslim Congress called by Saudi King Faisal and Moroccan King Hassan II $^{85}$. Morocco, where Messali stayed during the summer of 1969, hosted a conference during which the

\footnotetext{
78 "Revue de la presse", La Voix du peuple, avril 1960.

79 "Noms des journalistes et reporters invités à la conférence de presse du président Messali Hadj le 4 mai 1962 à Gouvieux-Chantilly", in AMH.

80 "Le MNA n'a aucun rapport avec l'OAS. Nous offrons au FLN une rencontre au sommet", Le Monde, 7 mai 1962.

81 "Conférence de presse du président Messali Hadj tenu le 4 mai 1962 à Gouvieux-Chantilly", in AMH.

82 "Questions faites au président Messali Hadj par les journalistes et les reporters français et étrangers lors de la conférence de presse du 4 mai 1962 et réponses de Messali Hadj", in AMH.

83 Nedjib Sidi Moussa, "La 'reconversion' du MNA (mars-juillet 1962) : entre le succès d'une prophétie et l'échec d'un prophète", in Le Maghreb et l'indépendance de l'Algérie, ed. Amar Mohand-Amer and Belkacem Benzenine, Paris, Oran Tunis, Karthala-CRASC-IRMC, 2012, p. 153-166.

${ }^{84}$ Maud S. Mandel, Muslim and Jews in France. History of a Conflict, Princeton, Princeton University Press, 2014, p. 57.

85 "Irons-nous à un congrès arabo-islamique pour régler nos problèmes ?", Le Cri du Peuple Algérien, n³2, juillet 1969.
} 
Palestinian issue was broadly discussed ${ }^{86}$. Messali enthusiastically welcomed this initiative and sent a telegram to the organizers on behalf of the Algerian People's Party (PPA):

"Le Parti du Peuple Algérien salue la Conférence Islamique, félicite ses initiateurs, organisateurs et ses participants. II leur demande respectueusement vu les dangers que court le monde arabo-islamique de prendre toutes les mesures adéquates pour libérer Jérusalem, récupérer les territoires arabes occupés et rendre la Palestine aux Palestiniens sans distinction de race ou de religion. Le PPA souhaite un grand succès à la Conférence et considère sa tenue comme un grand événement" ${ }^{187}$.

An article saluted the "success" of the Rabat conference and described Zionism as a creation aiming to "prevent Arabs from liberating themselves and building the Arab nation which was promised to them"88. This text reflected the international perspective of the last Messalists after 1962: their internationalism only articulated pan-Arabism with pan-Islamism, contrary to their broader solidarity with Cameroonian or Cypriot freedom fighters ${ }^{89}$, during the early stages of the anticolonial revolution. Coverage of the 1969 Rabat conference underlined the idealistic continuity with the 1935 Islamic-European congress of Geneva, which Messali had attended on behalf of the ENA. This illustrated the nostalgia for what was perceived as the golden age of Algerian nationalism, the time when Arslan published La Nation arabe" devoted to make Europe understand the wicked plots of imperialism and Zionism".

Succeeding his uncle Messali at the head of the PPA, Mohammed Mamchaoui continued to express his support for the Palestinian cause, as a part of the Arab nation. Following the end of Ramadan, the PPA published a leaflet on August 1, 1982 calling Arab-Muslim people and leaders to "face up to the elimination of the martyred Palestinian people"90. While insisting on Islamic fraternity and unity, this document also denounced the "treason" of the Arab League and the Muslim States. The text engaged with a series of recent events to illustrate its arguments, ranging from the Soviet invasion of Afghanistan, to the Iran-Iraq war and the Israeli intervention in Lebanon. But it mostly focused on the Palestinian cause:

\begin{abstract}
"Cette trahison des Etats arabes à l'endroit des Palestiniens a acculé Arafat à reconnaître toutes les résolutions des Nations Unies concernant leur cause depuis 1947 pour tenter de se préserver du pire ; c'est-à-dire la diasporisation d'un peuple palestinien errant, rejeté, méprisé, rudoyé et nié pour plusieurs siècles par l'Humanité entière.

Cependant, les Etats-Unis, Israël et le lobby juif international profitant de l'attitude arabe veulent la liquidation de la résistance palestinienne et l'extermination de son peuple pour instaurer une Pax Americana au Moyen-Orient pour établir leur ordre comme au Salvador et au Chili".
\end{abstract}

The analogy between the fate of Palestinians and the one of the Messalists, both political communities expelled from their homeland for different reasons, led Mamchaoui to call the Algerian people to build a "decent" State in order to provide an "efficient assistance to the Arab cause and to the martyred Palestinian people".

\footnotetext{
86 Éric Rouleau, "La conférence islamique a largement évoqué le problème palestinien", Le Monde, 25 septembre 1969.

87 "Télégramme du président Messali Hadj envoyé à la conférence islamique à Rabat", Le Cri du Peuple Algérien, $\mathrm{n}^{\circ} 33$, novembre 1969.

88 "La conférence islamique de Rabat a été une réussite", Le Cri du Peuple Algérien, n³3, novembre 1969.

89 "Le Cameroun devient-il une nouvelle Algérie?" and "Des troupes françaises débarquent à Chypre", $L a$ Voix du Peuple, $\mathrm{n}^{\circ}$ 25, [septembre 1956].

90 PPA, "Le PPA dénonce l'attitude des Etats arabes et appelle les peuples arabo-islamiques à exiger de leurs gouvernants de se dresser contre la liquidation du peuple palestinien martyr", Archives privées.
} 
This uncompromising solidarity for the Palestinian cause was not a new phenomenon. It had been an integral part of the Messalist movement since its creation. Nonetheless, twenty years after Algeria's independence, this also highlighted the PPA's isolation and the aging of its leadership established in France. Its international perspective was then strictly limited to the Arab-Muslim world, breaking with its progressive links, especially those acquired before and during the Algerian revolution among the European labour movement and other anti-imperialist organisations, at a point in time when the Messalist party could imagine a better fate for an inclusive nation. After supporting diplomatic initiatives from Arab monarchs who did not distinguish themselves by their political courage, the Messalist party felt surrounded by "treason" and resorted to a language that did not discriminate between Jews and Zionists. In Algeria, the "government statements denouncing Israel and imperialist-Zionist aggression" 91 undoubtedly met with considerable popular support in 1967 and during the Arab-Israeli conflicts. However, these anti-Zionist public statements of the Algerian Government "were made not only for domestic consumption"92 but also to embarrass their Arab rivals such as Egypt, as historian Jacob Abadi has noted. Furthermore, these statements coexisted with a "pragmatic tendency of the Algerian regime" towards the State of Israel, since the early stages of the Algerian revolution, despite the growing influence of the Islamist ideology.

${ }^{91}$ Richard A. Roughton, "Algeria and the June 1967 Arab-Israeli War", The Middle East Journal, 23-4 (Autumn, 1969), p. 444.

${ }^{92}$ Jacob Abadi, "Algeria's Policy toward Israel: Pragmatism and Rhetoric", The Middle East Journal, 56-4 (Autumn, 2002), p. 628. 